\title{
Influence of Urea and Ammonium Sulfate on Soil Acidity Indices in Lowland Rice Production
}

\author{
N. K. FAGERIA, ${ }^{1}$ A. B. DOS SANTOS,${ }^{1}$ AND M. F. MORAES ${ }^{2}$ \\ ${ }^{1}$ National Rice and Bean Research Center of Empresa Brasileira de Pesquisa \\ Agropecuaria (EMBRAPA), Santo Antônio de Goiás, Brazil \\ ${ }^{2}$ University of São Paulo, Luiz de Queiroz College of Agriculture, Piracicaba, \\ Brazil
}

\begin{abstract}
Urea and ammonium sulfate are principal nitrogen $(N)$ sources for crop production. Two field experiments were conducted during three consecutive years to evaluate influence of urea and ammonium sulfate application on grain yield, soil pH, calcium (Ca) saturation, magnesium ( $\mathrm{Mg}$ ) saturation, base saturation, aluminum (Al) saturation, and acidity $(H+A l)$ saturation in lowland rice production. Grain yield was significantly influenced by urea as well as ammonium sulfate fertilization. Soil $p H$ linearly decreased with the application of $N$ by ammonium sulfate and urea fertilizers. However, the magnitude of the $\mathrm{pH}$ decrease was greater by ammonium sulfate than by urea. The Ca and $M g$ saturations were decreased at the greater $N$ rates compared to low rates of $N$ by both the fertilizer sources. The Al and acidity saturation increased with increasing $N$ rates by both the fertilizer sources. However, these acidity indices were increased more with the application of ammonium sulfate compared with urea. Rice grain yield had negative associations with $\mathrm{pH}, \mathrm{Ca}$ saturation, $\mathrm{Mg}$ saturation, and base saturation and positive associations with $\mathrm{Al}$ and acidity saturation. This indicates that rice plant is tolerant to soil acidity.
\end{abstract}

Keywords Acidity saturation, base saturation, calcium saturation, Oryza sativa L., soil $\mathrm{pH}$

\section{Introduction}

Lowland and upland are two main rice production ecosystems. Lowland is also known as flooded rice, and in Brazil this system of rice culture is designated as irrigated rice. On a global basis, about $76 \%$ of the rice is produced from an irrigated lowland rice system (Fageria, Slaton, and Baligar 2003). Nitrogen is usually the most yield-limiting nutrient in lowland rice production. Intensive agricultural production systems have increased the use of nitrogen $(\mathrm{N})$ fertilizer in an effort to produce and sustain high crop yields. Nitrogen fertilizers are mostly applied in bands or broadcast. Urea and ammonium sulfate are the two main sources of inorganic N fertilizer for lowland rice (Fageria, Slaton, and Baligar 2003). Urea has about $46 \%$ of $\mathrm{N}$, and ammonium sulfate $\mathrm{N}$ content is about $21 \%$. In addition, ammonium sulfate also contains about $24 \%$ sulfur (S). Fertilizers with more $\mathrm{N}$ content are preferred over low-N fertilizers because of the lower cost of transport and application.

Received 27 November 2008; accepted 12 March 2009.

Address correspondence to N. K. Fageria, National Rice and Bean Research Center of EMBRAPA, Caixa Postal 179, Santo Antônio de Goiás, GO, CEP 75375-000, Brazil. E-mail: fageria@cnpaf.embrapa.br 
Nitrogen content is an important criterion; however, other factors should also be taken into consideration when choosing a fertilizer carriers. These factors include the content of nutrients other than the principal one, price of the fertilizer, chemical reactions in the soil, and nutrient availability to plants.

Recovery of $\mathrm{N}$ in crop plants is usually less than 50\% worldwide (Fageria and Baligar 2005). Worldwide, N recovery efficiency for cereal production (rice, wheat, sorghum, millet, barley, corn, oat, and rye is approximately 33\% (Raun and Johnson 1999). Fageria and Baligar (2001) reported N recovery efficiency of 39\% for lowland rice under Brazilian conditions. Low recovery of $\mathrm{N}$ in annual crops is associated with its loss by volatilization, leaching, surface runoff, denitrification, and plant canopy. Nowadays, the environmental as well as financial impact of $\mathrm{N}$ fertilizer use deserves increased attention. Field data on changes of soil acidity indices such as $\mathrm{pH}$, calcium $(\mathrm{Ca})$, and magnesium $(\mathrm{Mg})$ saturation, base saturation, aluminum $(\mathrm{Al})$ saturation, and acidity $(\mathrm{H}+\mathrm{Al})$ saturation with the application of ammonium sulfate and urea, two major $\mathrm{N}$ sources, are scarce for lowland rice under Brazilian conditions. The objective of this study was to evaluate influence of ammonium sulfate and urea on grain yield and soil acidity indices in lowland rice production.

\section{Materials and Methods}

Two field experiments involving lowland rice (Oryza sativa L.) were conducted during three consecutive years to evaluate influence of urea and ammonium sulfate application on grain yield and soil acidity indices in lowland rice grown on Inceptisols (sandy-clay loam, isothermic, mesic Typic Haplaquepts). The initial chemical and physical properties of these two experimental areas are presented in Table 1. Soil pH was measured in a 2:2.5 soil-water suspension. Phosphorus $(\mathrm{P})$, potassium $(\mathrm{K})$, copper $(\mathrm{Cu})$, zinc $(\mathrm{Zn})$, iron $(\mathrm{Fe})$, and manganese $(\mathrm{Mn})$ were extracted by the Mehlich 1 extracting solution [0.05 M

\section{Table 1}

Soil chemical and physical properties of two experimental areas (0-20 cm deep) before the application of $\mathrm{N}$ treatments

\begin{tabular}{|c|c|c|}
\hline Soil property & $\begin{array}{c}\text { Ammonium } \\
\text { sulfate experiment }\end{array}$ & Urea experiment \\
\hline $\mathrm{pH}$ in $\mathrm{H}_{2} \mathrm{O}$ & 5.5 & 4.8 \\
\hline Organic matter $\left(\mathrm{g} \mathrm{kg}^{-1}\right)$ & 26 & 9 \\
\hline $\mathrm{P}\left(\mathrm{mg} \mathrm{kg}^{-1}\right)$ & 19.2 & 24.5 \\
\hline $\mathrm{K}\left(\mathrm{mg} \mathrm{kg}^{-1}\right)$ & 38 & 34 \\
\hline $\mathrm{Ca}\left(\mathrm{cmol}_{\mathrm{c}} \mathrm{kg}^{-1}\right)$ & 3.7 & 1 \\
\hline $\operatorname{Mg}\left(\mathrm{cmol}_{\mathrm{c}} \mathrm{kg}^{-1}\right)$ & 1.7 & 0.5 \\
\hline $\mathrm{Al}\left(\mathrm{cmol}_{\mathrm{c}} \mathrm{kg}^{-1}\right)$ & 0.3 & 1.5 \\
\hline $\mathrm{Cu}\left(\mathrm{mg} \mathrm{kg}^{-1}\right)$ & 2.9 & 5.1 \\
\hline $\mathrm{Zn}\left(\mathrm{mg} \mathrm{kg}^{-1}\right)$ & 2.9 & 4.9 \\
\hline $\mathrm{Fe}\left(\mathrm{mg} \mathrm{kg}^{-1}\right)$ & 227 & 462 \\
\hline $\operatorname{Mn}\left(\mathrm{mg} \mathrm{kg}^{-1}\right)$ & 60 & 14 \\
\hline Clay $\left(\mathrm{g} \mathrm{kg}^{-1}\right)$ & 305 & 332 \\
\hline Silt $\left(\mathrm{g} \mathrm{kg}^{-1}\right)$ & 225 & 140 \\
\hline Sand $\left(\mathrm{g} \mathrm{kg}^{-1}\right)$ & 470 & 538 \\
\hline
\end{tabular}


hydrochloric acid $(\mathrm{HCl})+0.0125 \mathrm{M}$ sulfuric acid $\left.\left(\mathrm{H}_{2} \mathrm{SO}_{4}\right)\right]$. Phosphorus was determined colorimetrically, and $\mathrm{K}, \mathrm{Cu}, \mathrm{Zn}, \mathrm{Fe}$, and $\mathrm{Mn}$ were found by atomic absorption spectroscopy. Calcium, $\mathrm{Mg}$, and $\mathrm{Al}$ were extracted with $1 \mathrm{M}$ potassium chloride $(\mathrm{KCl})$. Aluminum was determined by titration with sodium hydroxide $(\mathrm{NaOH})$, and $\mathrm{Ca}$ and $\mathrm{Mg}$ were determined by titration with ethylenediaminetetraacetic acid (EDTA). Organic matter was determined by the Walkley-Black method, and soil texture was found by the pipette method. Soil analysis methods used in this study are described in a soil analysis manual published by EMBRAPA (1997).

In the ammonium sulfate experiment, the $\mathrm{N}$ rates used were $0,30,60,90,120,150$, 180 , and $210 \mathrm{~kg} \mathrm{ha}^{-1}$, whereas in the urea experiment, $\mathrm{N}$ rates were $0,50,100,150$, and 200 $\mathrm{kg} \mathrm{ha}^{-1}$. One third of $\mathrm{N}$ in the ammonium sulfate experiment was applied at sowing, and the remainder was topdressed twice, at equal rates, at 45 and 70 days after sowing (DAS). In the urea experiment, half of the $\mathrm{N}$ was applied at sowing and the remaining was topdressed at 45 DAS. In the ammonium sulfate experiment, treatments were replicated four times in a randomized block design. In the urea experiment, treatments were replicated three times in a randomized bloc design. Plot size was 5 by $4 \mathrm{~m}$ in ammonium sulfate experiment and 9.6 by $5 \mathrm{~m}$ in the urea experiment. In both the experiments, $52 \mathrm{~kg} \mathrm{P} \mathrm{ha}^{-1}$ as triple superphosphate and $100 \mathrm{~kg} \mathrm{~K} \mathrm{ha}^{-1}$ as potassium chloride were applied as basal fertilizers in bands at the time of sowing each year. In the urea experiment, initial $\mathrm{pH}, \mathrm{Ca}$, and $\mathrm{Mg}$ contents were low. Hence, $4 \mathrm{Mg}$ dolomitic lime ha ${ }^{-1}$ was applied and incorporated 4 weeks before sowing the first crop.

Flooded rice cultivar Metica 1 was sown in the ammonium sulfate experiment, and 12 genotypes were sown in the urea experiment, with 4 rows of $5 \mathrm{~m}$ each for each genotype. Sowing was done manually at a spacing of $20 \mathrm{~cm}$ between rows, using 90 seeds per meter row. Rice plots were flooded about 30 DAS to a depth of 10 to $15 \mathrm{~cm}$ of standing water, remained flooded during the crop growth period, and drained 1 week before harvest. Experiments were repeated for 3 years in the same areas, and after the harvest of the third rice crop, soil samples were taken at 0-20 cm deep from each plot to determine chemical properties. About 30 cores were taken from each plot to make one composite sample. Soil samples were dried and ground, and chemical properties were determined by methods described in the manual of soil analysis of EMBRAPA (1997). Relative grain yield and soil acidity indices were calculated using following formulas:

Relative grain yield $(\%)=($ Grain yield at a determined $\mathrm{N}$ rate/ Maximum grain yield at a determined $\mathrm{N}$ rate) $\times 100$

Ca saturation $(\%)=\left(\mathrm{Ca}^{2+} / \mathrm{CEC}\right) \times 100$, where CEC is cation exchange capacity in $\mathrm{cmol}_{\mathrm{C}} \mathrm{kg}^{-1}=\left[\Sigma\left(\mathrm{Ca}^{2+}, \mathrm{Mg}^{2+}, \mathrm{K}^{+}, \mathrm{H}^{+}, \mathrm{Al}^{3+}\right)\right]$

$\operatorname{Mg}$ saturation $(\%)=\left(\mathrm{Mg}^{2+} / \mathrm{CEC}\right) \times 100$

Base saturation $(\%)=\left[\Sigma\left(\mathrm{Ca}^{2+}, \mathrm{Mg}^{2+}, \mathrm{K}^{+}\right) /(\mathrm{CEC})\right] \times 100$

Al saturation $(\%)=\left[(\mathrm{Al}) / \Sigma\left(\mathrm{Ca}^{2+}, \mathrm{Mg}^{2+}, \mathrm{K}^{+}, \mathrm{Al}^{3+}\right)\right] \times 100$

Acidity saturation $(\%)=\left(\mathrm{H}^{+}+\mathrm{Al}^{3+} / \mathrm{CEC}\right) \times 100$

Regression analysis was used to test treatment effects. Appropriate regression equations were selected on the basis of probability level significance and greater $R^{2}$ values. 


\section{Results and Discussion}

\section{Grain Yield}

Grain yield expressed in relative yield was significantly increased by urea as well as ammonium sulfate fertilization, and the increase was in a quadratic fashion (Figure 1). In fertilizer experiments, $90 \%$ of the relative yield is considered as an economic index, and this index was used to calculate adequate $\mathrm{N}$ rate (Figure 1). Ninety percent of the relative yield (which corresponds to $5750 \mathrm{~kg}_{\text {grain }} \mathrm{ha}^{-1}$ ) was obtained with the application of $84 \mathrm{~kg} \mathrm{~N} \mathrm{ha}^{-1}$ in the case of ammonium sulfate. Similarly, in the case of urea, $90 \%$ of the relative grain yield (corresponds to $4811 \mathrm{~kg}_{\text {grain }} \mathrm{ha}^{-1}$ ) was obtained with the application of $130 \mathrm{~kg} \mathrm{~N} \mathrm{ha}^{-1}$. Singh et al. (1998) reported that the maximum average grain yield of $7700 \mathrm{~kg} \mathrm{ha}^{-1}$ of 20 lowland rice genotypes was obtained at 150 to $200 \mathrm{~kg} \mathrm{~N} \mathrm{ha}^{-1}$ at the International Rice Research Institute in the Philippines. Aulakh et al. (2000) reported that flooded rice responded to $\mathrm{N}$ rates up to $120 \mathrm{~kg} \mathrm{~N} \mathrm{ha}^{-1}$ on sandy loam soils in India. In the Philippines, Dobermann et al. (2000) reported 80 to $100 \mathrm{~kg} \mathrm{~N} \mathrm{ha}^{-1}$ was used for maximal yields in the field experiments during the wet season (rainy period) and 120 to $150 \mathrm{~kg} \mathrm{~N} \mathrm{ha}^{-1}$ was used during the dry season. These authors also reported that $\mathrm{N}$ fertilization rates in Philippines for irrigated lowland rice, from 1992 onward, were increased from 108 to $120 \mathrm{~kg} \mathrm{~N} \mathrm{ha}^{-1}$ during the wet season and from 190 to $216 \mathrm{~kg} \mathrm{~N} \mathrm{ha}^{-1}$ during the dry season. Fageria and Baligar (1996) also reported significant increases in grain yields of lowland rice grown on an Inceptisol in the central part of Brazil. These authors reported that an average yield of 3 years $\left(5523 \mathrm{~kg} \mathrm{ha}^{-1}\right)$ of lowland rice was achieved with the application of $100 \mathrm{~kg} \mathrm{~N} \mathrm{ha}^{-1}$. Hence, results of this study are comparable with the results reported in the literature for $\mathrm{N}$ requirements of lowland rice.

\section{Soil Acidity Indices}

Soil $\mathrm{pH}$ was decreased linearly with increasing $\mathrm{N}$ rate by ammonium sulfate (0 to $210 \mathrm{~kg}$ $\mathrm{N} \mathrm{ha}^{-1}$ ) and urea (0 to $200 \mathrm{~kg} \mathrm{~N} \mathrm{ha}^{-1}$ ) (Table 2). The decrease in $\mathrm{pH}$ with ammonium sulfate was from 5.8 at $0 \mathrm{~N} \mathrm{ha}^{-1}$ rate to 5.2 at $210 \mathrm{~kg} \mathrm{~N}$ ha $^{-1}$. This means that the decrease

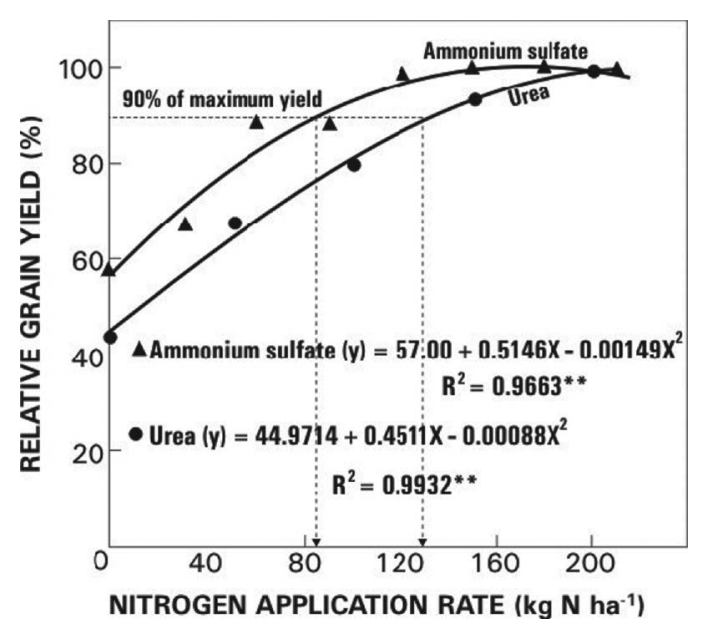

Figure 1. Relative grain yield of lowland rice as influenced by ammonium sulfate and urea sources. 
Table 2

Influence of $\mathrm{N}$ rate applied by ammonium sulfate and urea on soil $\mathrm{pH}$ after harvest of three lowland rice crops

\begin{tabular}{|c|c|c|c|}
\hline \multirow{2}{*}{$\begin{array}{l}\mathrm{N} \text { rate }\left(\mathrm{kg} \mathrm{ha}^{-1}\right) \\
\mathrm{NH}_{4}\left(\mathrm{SO}_{4}\right)_{2}\end{array}$} & \multicolumn{3}{|c|}{$\mathrm{N}$ rate $\left(\mathrm{kg} \mathrm{ha}^{-1}\right)$} \\
\hline & $\mathrm{pH}$ in $\mathrm{H}_{2} \mathrm{O}$ & Urea & $\mathrm{pH}$ in $\mathrm{H}_{2} \mathrm{O}$ \\
\hline 0 & 5.8 & 0 & 5.7 \\
\hline 30 & 5.8 & 50 & 5.6 \\
\hline 60 & 5.5 & 100 & 5.7 \\
\hline 90 & 5.4 & 150 & 5.5 \\
\hline 120 & 5.4 & 200 & 5.5 \\
\hline 150 & 5.4 & & \\
\hline 180 & 5.3 & & \\
\hline 210 & 5.2 & & \\
\hline Average & 5.5 & & 5.6 \\
\hline
\end{tabular}

${ }^{*},{ }^{* *}$ Significant at the $5 \%$ and $1 \%$ probability levels, respectively.

Notes. Regression analysis: $\mathrm{N}$ rate, ammonium sulfate $(X)$ vs $\mathrm{pH}(Y): Y=$ $5.7187-0.0026 X, R^{2}=0.3969^{* *}$; and $\mathrm{N}$ rate, urea $(X)$ vs $\mathrm{pH}(Y): Y=$ 5.6927-0.00092X, $R^{2}=0.2601^{*}$.

at the greatest $\mathrm{N}$ rate applied with ammonium sulfate was $12 \%$ compared with the lowest $\mathrm{N}$ rate for the same fertilizer. Similarly, the decrease in $\mathrm{pH}$ with urea fertilizer was 5.7 at the 0 rate ha ${ }^{-1}$ to 5.5 at $200 \mathrm{~kg} \mathrm{~N}^{-1}$. This decrease corresponds to $4 \%$ at the greatest $\mathrm{N}$ rate compared with the lowest $\mathrm{N}$ rate. Hence, the decrease in soil $\mathrm{pH}$ was greater with ammonium sulfate compared to urea. Ammonium sulfate fertilization accounted for about $40 \%$ variation in soil $\mathrm{pH}$, and urea fertilization accounted for $26 \%$ variation in soil $\mathrm{pH}$. Both the $\mathrm{N}$ fertilizer sources are acidic and their acid equivalencies [kg calcium carbonate $\left(\mathrm{CaCO}_{3}\right)$ required to neutralize acidity produced by $100 \mathrm{~kg}$ of fertilizers] are 110 for ammonium sulfate and 80 for urea (Fageria 1989). Decrease in soil $\mathrm{pH}$ has been reported by use of ammonium sulfate and urea (Hetrick and Schwab 1992). Stumpe and Vlek (1991) reported that a decrease in $\mathrm{pH}$ of tropical acid soils (Oxisols, Ultisols, and Alfisols) due to use of three $\mathrm{N}$ fertilizers was in the order of ammonium sulfate $>$ urea $>$ ammonium nitrate. These two fertilizer sources can acidify the soil by following reactions (Fageria 1989; Bolan and Hedley 2003):

$$
\begin{gathered}
\left(\mathrm{NH}_{4}\right)_{2} \mathrm{SO}_{4} \Leftrightarrow 2 \mathrm{NH}_{4}^{+}+\mathrm{SO}_{4}^{2-} \\
\mathrm{NH}_{4}^{+}+2 \mathrm{O}_{2} \Leftrightarrow \mathrm{NO}_{3}^{-}+2 \mathrm{H}^{+}+\mathrm{H}_{2} \mathrm{O} \\
\mathrm{CO}\left(\mathrm{NH}_{2}\right)_{2}+3 \mathrm{H}_{2} \mathrm{O} \Leftrightarrow 2 \mathrm{NH}_{4}^{+}+2 \mathrm{OH}^{-}+\mathrm{CO}_{2} \\
\mathrm{NH}_{4}^{+}+2 \mathrm{O}_{2} \Leftrightarrow \mathrm{NO}_{3}^{-}+2 \mathrm{H}^{+}+\mathrm{H}_{2} \mathrm{O}
\end{gathered}
$$

According to these equations, the ammonium $\left(\mathrm{NH}_{4}{ }^{+}\right)$ions are oxidized to yield nitrate $\left(\mathrm{NO}_{3}{ }^{-}\right)$ions or nitrification, which results in the release of $\mathrm{H}^{+}$ions, leading to soil acidification. Another reason for soil acidification by ammonium sulfate and urea is leaching of $\mathrm{NO}_{3}{ }^{-}$ions. During leaching of $\mathrm{NO}_{3}{ }^{-}$ions, they are accompanied by positively charged 
basic cations, such as $\mathrm{Ca}^{2+}, \mathrm{Mg}^{2+}$, and $\mathrm{K}^{+}$, to maintain the electric charge on the soil particles. During the leaching of these basic cations from soil particles, their sites are replaced by $\mathrm{H}^{+}$ions, which accelerates the acidification process (Bolan and Hedley 2003).

Calcium as well as $\mathrm{Mg}$ saturation decreased with increasing $\mathrm{N}$ rates by ammonium sulfate and urea fertilizers (Tables 3 and 4). The decrease in Ca saturation at $210 \mathrm{~kg} \mathrm{~N} \mathrm{ha}^{-1}$ supplied by ammonium sulfate was $23 \%$, and with urea application at $200 \mathrm{~kg} \mathrm{~N} \mathrm{ha}^{-1}$ it was $33 \%$ compared with the control treatment. Similarly, the decrease in $\mathrm{Mg}$ saturation was $2 \%$ at the greatest $\mathrm{N}$ application rate using ammonium sulfate as compared with the

Table 3

Influence of $\mathrm{N}$ rate applied by ammonium (AS) and urea on Ca saturation after harvest of three lowland rice crops

\begin{tabular}{lccc}
\hline $\begin{array}{l}\mathrm{N} \text { rate } \\
\mathrm{NH}_{4}\left(\mathrm{SO}_{4}\right)_{2}\end{array}$ & Ca saturation $(\%)$ & $\begin{array}{c}\mathrm{N} \mathrm{rate}\left(\mathrm{kg} \mathrm{ha}^{-1}\right) \\
\mathrm{CO}\left(\mathrm{NH}_{2}\right)_{2}\end{array}$ & Ca saturation $(\%)$ \\
\hline 0 & 22.7 & 0 & 31.6 \\
30 & 24.4 & 50 & 26.8 \\
60 & 21.0 & 100 & 28.0 \\
90 & 18.6 & 150 & 27.1 \\
120 & 20.3 & 200 & 23.8 \\
150 & 19.9 & & \\
180 & 19.6 & & 27.4 \\
210 & 18.4 & & \\
Average & 20.6 & & \\
\hline
\end{tabular}

${ }^{*},{ }^{* *}$ Significant at the $5 \%$ and $1 \%$ probability levels, respectively.

Notes. Regression analysis: $\mathrm{N}$ rate $\mathrm{AS}(X)$ vs. Ca sat. $(Y): Y=23.5510-$ $0.0421 X+0.000094 X^{2}, R^{2}=0.234^{* *}$; and $\mathrm{N}$ rate urea $(X)$ vs. Ca saturation $(Y): Y=$ $30.5133-0.0306 \mathrm{X}, R^{2}=0.3684^{*}$.

\section{Table 4}

Influence of $\mathrm{N}$ rate applied by ammonium sulfate (AS) and urea on $\mathrm{Mg}$ saturation after harvest of three lowland rice crops

\begin{tabular}{lccc}
\hline $\mathrm{N}$ rate & \multicolumn{2}{c}{$\begin{array}{c}\mathrm{N} \mathrm{rate}\left(\mathrm{kg} \mathrm{ha}^{-1}\right) \\
\mathrm{CO}\left(\mathrm{NH}_{2}\right)_{2}\end{array}$} & Mg saturation (\%) \\
$\mathrm{NH}_{4}\left(\mathrm{SO}_{4}\right)_{2}$ & Mg saturation $(\%)$ & 0 & 11.7 \\
0 & 9.1 & 50 & 9.5 \\
30 & 10.4 & 100 & 9.7 \\
60 & 9.0 & 150 & 9.0 \\
90 & 8.0 & 200 & 8.1 \\
120 & 7.9 & & \\
150 & 8.8 & & 9.6 \\
180 & 7.8 & & \\
210 & 8.9 & & \\
Average & 8.7 & & \\
\hline
\end{tabular}

**, ${ }^{\mathrm{NS}}$ Significant at the $1 \%$ probability level and nonsignificant, respectively.

Notes. Regression analysis: $\mathrm{N}$ rate $\mathrm{AS}(X)$ vs. $\mathrm{Mg}$ saturation $(Y): Y=9.8208-0.0211 X+$ $0.000073 X^{2}, R^{2}=0.1077^{\mathrm{NS}}$; and $\mathrm{N}$ rate urea $(X)$ vs. $\mathrm{Mg}$ saturation $(Y): Y=11.3723-$ $0.0242 X+0.000043 X^{2}, R^{2}=0.6205^{* *}$. 
control treatment. The decrease in $\mathrm{Mg}$ saturation at the greatest $\mathrm{N}$ rate with urea application was $44 \%$ compared with the control treatment. The decrease in $\mathrm{Ca}$ and $\mathrm{Mg}$ saturation at greater $\mathrm{N}$ rates may be associated with increase in acidity at greater $\mathrm{N}$ rates and decrease in concentration of these elements. An increase in acidity decreases the concentrations of $\mathrm{Ca}$ and Mg in Brazilian Inceptisols (Fageria and Baligar 1999).

Base saturation is an important soil acidity index for predicting fertility behavior of tropical acidic soils (Fageria and Baligar 2001). Base saturation decreased linearly with increasing $\mathrm{N}$ rates by both the sources of $\mathrm{N}$ fertilizer (Table 5). The decrease in base saturation with application of $210 \mathrm{~kg} \mathrm{~N} \mathrm{ha}^{-1}$ with ammonium sulfate was $27.8 \%$ compared with $32.2 \%$ at the control treatment. Similarly, the base saturation at the control treatment of urea was $44.4 \%$, which decreased to $32.5 \%$ at the greatest $\mathrm{N}$ rate. The decrease in base saturation at the greater $\mathrm{N}$ rate was associated with decreases in $\mathrm{Ca}$ and $\mathrm{Mg}$ saturation (Tables 3 and 4). At the greater $\mathrm{N}$ rates, $\mathrm{pH}$ was than the $\mathrm{pH}$ at low $\mathrm{N}$ rates under both the $\mathrm{N}$ sources. At low $\mathrm{pH}, \mathrm{Al}^{3+}$ is the predominant exchangeable cation on clay minerals. As the $\mathrm{pH}$ is raised, the $\mathrm{Al}^{3+}$ hydrolyzes, freeing the exchangeable sites for $\mathrm{Ca}^{2+}$ and $\mathrm{Mg}^{2+}$, and results in an increase of base saturation (Thomas and Hargrove 1984).

The Al saturation increased linearly with the increasing $\mathrm{N}$ rates by ammonium sulfate as well as urea fertilization (Table 6). The increase in Al saturation was about twofold at the $210 \mathrm{~kg} \mathrm{~N} \mathrm{ha}^{-1}$ supplied by ammonium sulfate compared with control treatment. The increase in $\mathrm{Al}$ saturation with the application of $200 \mathrm{~kg} \mathrm{~N} \mathrm{ha}^{-1}$ by urea was about fourfold compared with the control treatment of this fertilizer. Similarly, the increase in acidity saturation was significant and quadratic with increasing $\mathrm{N}$ rates by both the fertilizer sources (Table 7). The increase in Al saturation and acidity saturation was associated with a decrease in base saturation with increasing $\mathrm{N}$ rates. Another reason for increase of these acidity indices was a decrease in $\mathrm{pH}$ with increasing $\mathrm{N}$ rates. The release of $\mathrm{Al}$ and $\mathrm{Al}+\mathrm{H}$ from various minerals is greatly dependent on $\mathrm{pH}$, and these elements significantly increased in the soil solution with decreasing soil pH (Mengel et al. 2001).

\section{Table 5}

Influence of $\mathrm{N}$ rate applied by ammonium sulfate and urea on base saturation after harvest of three lowland rice crops

\begin{tabular}{lccc}
\hline $\begin{array}{l}\mathrm{N} \text { rate }\left(\mathrm{kg} \mathrm{ha}^{-1}\right) \\
\mathrm{NH}_{4}\left(\mathrm{SO}_{4}\right)_{2}\end{array}$ & Base saturation (\%) & $\begin{array}{c}\mathrm{N} \text { rate }\left(\mathrm{kg} \mathrm{ha}^{-1}\right) \\
\mathrm{CO}\left(\mathrm{NH}_{2}\right)_{2}\end{array}$ & Base saturation (\%) \\
\hline \multirow{3}{*}{30} & 32.2 & 0 & 44.4 \\
60 & 35.3 & 50 & 36.9 \\
90 & 30.5 & 100 & 38.4 \\
120 & 27.0 & 150 & 36.7 \\
150 & 28.5 & 200 & 32.5 \\
180 & 29.2 & & \\
210 & 27.9 & & 37.7 \\
Average & 27.8 & & \\
\hline
\end{tabular}

*, ** Significant at the $5 \%$ and $1 \%$ probability level, respectively.

Notes. Regression analysis: $\mathrm{N}$ rate ammonium sulfate $(X)$ vs. base saturation $(Y): Y=32.7292-$ $0.0280 X, R^{2}=0.1945^{*}$; and $\mathrm{N}$ rate urea $(X)$ vs. base saturation $(Y): Y=42.5666-0.0479 X$, $R^{2}=0.4529^{* *}$. 
Table 6

Influence of $\mathrm{N}$ rate applied by ammonium sulfate and urea on aluminum saturation after harvest of three lowland rice crops

\begin{tabular}{|c|c|c|c|}
\hline $\begin{array}{l}\mathrm{N} \text { rate } \\
\mathrm{NH}_{4}\left(\mathrm{SO}_{4}\right)_{2}\end{array}$ & Al saturation $(\%)$ & $\begin{array}{c}\mathrm{N} \text { rate }\left(\mathrm{kg} \mathrm{ha}^{-1}\right) \\
\mathrm{CO}\left(\mathrm{NH}_{2}\right)_{2}\end{array}$ & $\mathrm{Al}$ saturation $(\%)$ \\
\hline 0 & 6.4 & 0 & 1.7 \\
\hline 30 & 5.9 & 50 & 3.7 \\
\hline 60 & 5.1 & 100 & 3.8 \\
\hline 90 & 6.7 & 150 & 4.5 \\
\hline 120 & 4.2 & 200 & 6.8 \\
\hline 150 & 8.4 & & \\
\hline 180 & 10.3 & & \\
\hline 210 & 11.2 & & \\
\hline Average & 7.3 & & 4.1 \\
\hline
\end{tabular}

** Significant at the $1 \%$ probability level.

Notes. Regression analysis: $\mathrm{N}$ rate ammonium sulfate $(X)$ vs. Al saturation $(Y)$ : $Y=4.6604+0.0248 \mathrm{X}, R^{2}=0.2162^{* *}$; and $\mathrm{N}$ rate urea $(X)$ vs. Al saturation $(Y): Y=$ $1.93+0.0217 X, R^{2}=0.5476^{* *}$.

Table 7

Influence of $\mathrm{N}$ rate applied by ammonium sulfate (AS) and urea on acidity saturation after harvest of three lowland rice crops

\begin{tabular}{lccc}
\hline $\begin{array}{l}\mathrm{N} \text { rate } \\
\mathrm{NH}_{4}\left(\mathrm{SO}_{4}\right)_{2}\end{array}$ & Acidity saturation $(\%)$ & $\begin{array}{c}\mathrm{N} \mathrm{rate}\left(\mathrm{kg} \mathrm{ha}^{-1}\right) \\
\mathrm{CO}\left(\mathrm{NH}_{2}\right)_{2}\end{array}$ & Acidity saturation (\%) \\
\hline 0 & 67.8 & 0 & 55.6 \\
30 & 64.7 & 50 & 63.1 \\
60 & 69.5 & 100 & 61.6 \\
90 & 73.0 & 150 & 63.3 \\
120 & 71.5 & 200 & 67.5 \\
150 & 70.8 & & \\
180 & 72.1 & & \\
210 & 72.2 & & 62.2 \\
Average & 70.2 & & \\
\hline
\end{tabular}

${ }^{*}$ Significant at the $5 \%$ probability level.

Notes. Regression analysis: $\mathrm{N}$ rate AS $(X)$ vs. acidity saturation $(Y): Y=66.1739+$ $0.0646 X-0.00017 X^{2}, R^{2}=0.2216^{*}$; and $\mathrm{N}$ rate urea $(X)$ vs. acidity saturation $(Y): Y=$ $56.9714+0.0664 X-0.000092 X^{2}, R^{2}=0.4586^{*}$.

\section{Relationship between Soil Acidity Indices and Grain Yield}

In ammonium sulfate as well as urea experiments, grain yield was negatively and significantly associated with $\mathrm{pH}$, base saturation, $\mathrm{Ca}$ saturation, and $\mathrm{Mg}$ saturation, but $\mathrm{Mg}$ saturation in the ammonium sulfate experiment was not significant (Table 8). Aluminum saturation and acidity saturation had positive and significant association with grain yield, except that the $\mathrm{Al}$ saturation in the ammonium sulfate was not significant. The negative 


\section{Table 8}

Relationship between soil acidity indices $(X)$ and grain yield $(Y)$ of ammonium sulfate and urea experiments

\begin{tabular}{|c|c|c|}
\hline Soil property & Regression equation & $R^{2}$ \\
\hline & Ammonium sulfate experiment & \\
\hline $\mathrm{pH}$ in $\mathrm{H}_{2} \mathrm{O}$ & $Y=1577.61-1863.3680 X$ & $0.2621^{* *}$ \\
\hline Base saturation $(\%)$ & $Y=8711.6960-104.9912 X$ & $0.1901^{*}$ \\
\hline Ca saturation $(\%)$ & $Y=8342.7040-133.8276 X$ & $0.1739^{*}$ \\
\hline $\mathrm{Mg}$ saturation (\%) & $Y=7618.8560-232.3198 X$ & $0.1122^{\mathrm{NS}}$ \\
\hline Al saturation $(\%)$ & $Y=5432.0290+20.9815 X$ & $0.0272^{\mathrm{NS}}$ \\
\hline \multirow[t]{2}{*}{ Acidity saturation (\%) } & $Y=-1787.1090+104.9868 X$ & $0.1901^{*}$ \\
\hline & Urea experiment & \\
\hline $\mathrm{pH}$ in $\mathrm{H}_{2} \mathrm{O}$ & $Y=27332.72-4149.7830 X$ & $0.2070^{* *}$ \\
\hline Base saturation $(\%)$ & $Y=9259.0960-136.7193 X$ & $0.3881^{* *}$ \\
\hline Ca saturation $(\%)$ & $Y=8678.0870-166.9514 X$ & $0.2905^{* *}$ \\
\hline Mg saturation (\%) & $Y=9825.5170-596.5399 X$ & $0.5776^{* *}$ \\
\hline Al saturation $(\%)$ & $Y=2673.6630+346.2711 X$ & $0.4238^{* *}$ \\
\hline Acidity saturation (\%) & $Y=-4412.9740+136.7215 X$ & $0.3881^{* *}$ \\
\hline
\end{tabular}

association with $\mathrm{pH}$, base saturation, and $\mathrm{Ca}$ and $\mathrm{Mg}$ saturation, as well as positive association with $\mathrm{Al}$ saturation and acidity saturation, indicates tolerance of rice crop to acidity. Fageria and Baligar (1999) reported that among important annual crops such as wheat, corn, soybean, and dry bean, rice is the most tolerant to soil acidity. Fageria and Santos (1998) reported that lowland rice grain significantly increased with increasing Al concentration in the range of 0 to $3.83 \mathrm{cmol}_{\mathrm{c}} \mathrm{kg}^{-1}$ of soil. Similarly, these authors also reported linear increase in lowland rice yield, when $\mathrm{Al}$ saturation in the soil was increased from 0 to $30 \%$. The exact mechanism by which some plant species tolerate a high level of acidity is still debated. Several hypotheses have been suggested, but much research remains to be done to verify these hypothesis. Some important hypotheses are that (1) tolerant plants either prevent excess $\mathrm{Al}$ absorption by roots or detoxify $\mathrm{Al}$ after it has been absorbed (Foy 1984) and (2) acid-tolerant species or cultivars increase the growth medium $\mathrm{pH}$ and thus reduce $\mathrm{Al}$ solubility and toxicity. In contrast, acid-sensitive species or cultivars lower the $\mathrm{pH}$ of the growth medium, thereby increasing Al solubility and toxicity (Foy 1974), Altolerant species may control excess $\mathrm{Al}$ in roots and restrict its transport to shoots (Fageria and Carvalho 1982), and Al-tolerant plant species contain high levels of organic acids that chelate and detoxify Al within the plant (Foy 1974; Fageria, Baligar, and Wright 1988). Mendonça et al. (2005) reported that Al-tolerant rice cultivar showed a greater ability to adjust its cations balance, changing the $\mathrm{pH}$ to values that favored less $\mathrm{Al}$ uptake and greater tolerance to $\mathrm{Al}$.

A genetic basis for acidity tolerance has been reported for many annual crops, including rice (Yang et al. 2004). Acidity tolerance in rice is reported to be controlled by multiple genes (Nguyen et al. 2002; Ma et al. 2002). Nguyen et al. (2001) detected a total of 20 QTLs, distributed over 10 of 12 rice chromosomes, that control root growth under $\mathrm{Al}$ stress, whereas Ma et al. (2002) found three putative quantitative trait locuses (QTLs) that control $\mathrm{Al}$ tolerance in Japonica rice on chromosomes 1, 2, and 6. 


\section{Conclusions}

Relative grain yield of lowland rice increased significantly by application of $\mathrm{N}$ by ammonium sulfate and urea. Grain yield had quadratic responses from both sources of $\mathrm{N}$. Increasing $\mathrm{N}$ rates by both ammonium sulfate and urea fertilizers have a tendency to decrease soil $\mathrm{pH}, \mathrm{Ca}$ and $\mathrm{Mg}$ saturation, and base saturation and increase $\mathrm{Al}$ saturation and acidity $(\mathrm{H}+\mathrm{Al})$ saturation. This means that both the fertilizers increase soil acidity. However, the magnitude of acidity increase was greater with the application of ammonium sulfate than with urea. Grain yield was significantly and negatively associated with $\mathrm{pH}$, base saturation, and $\mathrm{Ca}$ saturation and significantly and positively associated with $\mathrm{Al}$ and acidity saturation. This indicates tolerance of rice plants to soil acidity.

\section{References}

Aulakh, M., T. S. Khera, J. W. Doran, K. Singh, and B. Singh. 2000. Yield and nitrogen dynamics in a rice-wheat system using green manure and inorganic fertilizer. Soil Science Society of America Journal 64:1867-1876.

Bolan, N. S., and M. J. Hedley. 2003. Role of carbon, nitrogen, and sulfur cycles in soil acidification. In Handbook of soil acidity, ed. Z. Rengel, 29-56. New York: Marcel Dekker.

Dobermann, A., D. Dawe, R. P. Roetter, and K. G. Cassman. 2000. Reversal of rice yields decline in a long-term continuous cropping experiment. Agronomy Journal 67:233-306.

EMBRAPA (Empresa Brasileira de Pesquisa Agropecuaria). 1997. Manual for methods of soil analysis, 2nd edition. Rio de Janeiro, Brazil: National Service for Soil Survey and Soil Conservation.

Fageria, N. K. 1989. Tropical soils and physiological aspects of crop yield. Brasilia, Brazil: EMBRAPA.

Fageria, N. K., and V. C. Baligar. 1996. Response of lowland rice and common bean grown in rotation to soil fertility levels on a varzea soil. Fertilizer Research 45:13-20.

Fageria, N. K., and V. C. Baligar. 1999. Growth and nutrient concentrations of common bean, lowland rice, corn, soybean, and wheat at different soil pH on an Inceptisol. Journal of Plant Nutrition 22:1495-1507.

Fageria, N. K., and V. C. Baligar. 2001. Lowland rice response to nitrogen fertilization. Communications in Soil Science and Plant Analysis 32:1405-1429.

Fageria, N. K., and V. C. Baligar. 2005. Enhancing nitrogen use efficiency in crop plants. Advances in Agronomy 80:97-185.

Fageria, N. K., V. C. Baligar, and R. J. Wright. 1988. Aluminum toxicity in crop plants. Journal of Plant Nutrition 11:303-319.

Fageria, N. K. and Carvalho, J. R. P. 1982. Influence of aluminum in nutrient solutions on chemical composition in upland rice cultivars. Plant and Soil 69:31-44.

Fageria, N. K., and A. B. Santos. 1998. Rice and common bean growth and nutrient concentrations as influenced by aluminum on an acid lowland soil. Journal of Plant Nutrition 21:903-912.

Fageria, N. K., N. A. Slaton, and V. C. Baligar. 2003. Nutrient management for improving lowland productivity and sustainability. Advances in Agronomy 80:63-152.

Foy, C. D. 1974. Effects of aluminum in plant growth. In The plant root and its environment, ed. E.W. Carson, 601-642. Charlottesville: University Press of Virginia.

Foy, C. D. 1984. Physiological effects of hydrogen, aluminum, and manganese toxicities in acid soil. In Soil acidity and liming, 2nd ed., 57-97. Madison, Wisc.: ASA, CSSA, and SSSA.

Hetrick, J. A., and A. P. Schwab. 1992. Changes in aluminum and phosphorus solubility are in response to long-term fertilization. Soil Science Society of America Journal 56:755-761.

Ma, J. F., R. F. Shen., Z. Q. Zhao, M. Wissuwa, Y. Takeuchi, T. Ebitani, and M. Yano. 2002. Response of rice to $\mathrm{Al}$ stress and identification of quantitative trait for $\mathrm{Al}$ tolerance. Plant Cell Physiology 43:652-659. 
Mendonça, R. J., J. Cambraia, M. A. Oliva, and J. A. Oliveira.. 2005. Rice cultivars ability to change nutrient solution $\mathrm{pH}$ in the presence of aluminum. Pesquisa Agropecuaria Brasileira 40:447-452.

Mengel, K., E. A. Kirkby, H. Kosegarten, and T. Appel. 2001. Principles of plant nutrition, 5th ed. Dordrecht, the Netherlands: Kluwer Academic Publishers.

Nguyen, V. T., M. D. Burrow, H. T. Nguyen, B. T. Le, and A. H. Paterson. 2001. Molecular mapping of genes conferring aluminum tolerance in rice (Oryza sativa L.). Theoretical Applied Genetics 102:1002-1010.

Nguyen, V. T., B. D. Nguyen, S. Sarkarung, C. Martinez, A. H. Paterson, and H. Nguyen. 2002. Mapping of genes controlling aluminum tolerance in rice: Comparison of different genetic background. Molecular Genetic Genomics 267:772-780.

Raun, W. R., and A. Johnson. 1999. Improving nitrogen use efficiency for cereal production. Agronomy Journal 91:357-363.

Singh, U., J. K. Ladha, E. G. Castillo, G. Punzalan, A. Tirol-Padre, and M. Duqueza. 1998. Genotype variation in nitrogen use efficiency in medium- and long-duration rice. Field Crops Research $58: 35-53$.

Stumpe, J. M., and P. L. G. Vlek. 1991. Acidification induced by nitrogen sources in columns of selected tropical soils. Soil. Science Society of America Journal 55:145-151.

Thomas, G. W. and W. L. Hargrove. 1984. The chemistry of soil acidity. In Soil acidity and liming, 2nd ed., 3-56. Madison, Wisc.: ASA, CSSA, and SSSA.

Yang, X., W. Wang, Z. Ye, Z. He, and V. C. Baligar. 2004 Physiological and genetic aspects of crop plant adaptation to elemental stresses in acid soils. In The red soils of China: Their nature, management, and utilization, ed. M. J. Wilson, Z. He, and X. Yang, 171-218. Dordrecht, the Netherlands: Kluwer Academic Publishers. 